\title{
Vascular endothelial growth factor signals through platelet-derived growth factor receptor $\beta$ in meningiomas in vitro
}

\author{
C Pfister ${ }^{*, 1}$, H Pfrommer', MS Tatagiba' and F Roser' \\ 'Department of Neurosurgery, University of Tuebingen, Hoppe-Seyler-Strasse 3, Tuebingen 72076, Germany
}

BACKGROUND: Vascular endothelial growth factor (VEGF)-mediated angiogenesis mediates tumour growth and metastasis. Meningiomas are primarily benign, slow-growing, highly vascularised tumours. Aside from VEGF, there is little data on the function of major angiogenic proteins in meningiomas.

METHODS: The VEGFA, platelet-derived growth factor B (PDGFB), and their respective receptors - VEGF receptor 2 (KDR) and PDGF receptor $\beta$ (PDGFR $\beta$ ) - were quantified using real-time PCR and a TaqMan Protein Assay in meningiomas in vivo and in vitro. The effect of VEGFA and PDGFB on cell proliferation and the tyrosine phosphorylation of PDGFR $\beta$ were examined.

RESULTS: Most meningiomas displayed no KDR protein expression but elevated PDGFR $\beta$ levels. Exogenous VEGFA stimulation significantly increased cell proliferation. The PDGFR $\beta$ inhibition before stimulation with VEGFA abolished the proliferative stimuli. The VEGFA induced concentration-dependent PDGFR $\beta$ tyrosine phosphorylation comparable to PDGFB-induced PDGFR $\beta$ tyrosine phosphorylation. The PDGFR $\beta$ inhibitors gambogic acid, sunitinib, and tandutinib equally impaired the migration of meningioma cells. In addition, gambogic acid suppressed the VEGFA-induced PDGFR $\beta$ tyrosine phosphorylation.

CONCLUSION: Collectively, our data suggest that VEGFA primarily regulates VEGF-mediated migration through PDGFR $\beta$ in meningiomas. The inhibitory effect of gambogic acid and tandutinib against meningioma growth in vitro suggests that selective PDGFR $\beta$ inhibitors, in combination with VEGF inhibitors, should be evaluated further as potential therapies for recurrent and malignant meningiomas.

British Journal of Cancer (2012) I 07, I702-1713. doi:I0.1038/bjc.2012.459 www.bjcancer.com

Published online 9 October 2012

(c) 2012 Cancer Research UK

Keywords: meningioma; VEGF; PDGFR $\beta$; gambogic acid; tandutinib

Meningiomas are the most common type of intracranial tumours. They originate from the arachnoidal cap cells of the meningeal cover of the spinal cord and brain and account for $\sim 13-26 \%$ of all intracranial neoplasms (Riemenschneider et al, 2006; Louis et al, 2007). The conventional treatment for meningiomas is surgery (McMullen and Stieber, 2004). The 5-year recurrence rates after complete resection in benign, atypical, and anaplastic meningiomas were $3 \%, 38 \%$, and $78 \%$, respectively, for World Health Organisation (WHO) grade I meningiomas, the recurrence rate increased after incomplete resection from $7.5 \%$ to $9.8 \%$ at 10 years and $9.3 \%$ to $25.6 \%$ at 20 years (Jääskeläinen, 1986; Nakasu et al, 2009). The potential for malignancy is unresolved, due to a frequent discordance between histology and biology (Mahmood et al, 1993; Schittenhelm et al, 2006). Meningiomas are categorised into three grades by the WHO, and there are several subtypes based on histology.

Angiogenesis is essential for the enlargement of any solid tumour. Vascular endothelial growth factor (VEGF) is the key regulator of pathological angiogenesis (Ferrara et al, 2003). The VEGFA is the most abundant member of the VEGF family (Holmes and Zachary, 2005; Yamazaki and Morita, 2006), which comprising several isoforms, such as $\mathrm{VEGF}_{165}$, through alternative splicing.

\footnotetext{
*Correspondence: Dr C Pfister;

E-mail: christina.pfister@med.uni-tuebingen.de

revised II September 2012; accepted 12 September 2012; published online 9 October 2012
}

There are three VEGF receptor tyrosine kinases (VEGFR1-3), but VEGFA only binds to VEGFR1 (FLT1) and VEGFR2 (KDR), and most of the signal transduction is mediated by the latter (Cross et al, 2003).

The VEGF and VEGFRs mediate angiogenesis in various brain tumours (Nishikawa et al, 1998; Huang et al, 2005). Although VEGF is upregulated in meningiomas (Provias and Claffey, 1997; Christov et al, 1999; Lamszuz et al, 2000; Park et al, 2000; Yamasaki, 2000), it is unknown whether the degree of malignancy correlates with the expression of VEGF (Provias and Claffey, 1997; Lamszuz et al, 2000; Yamasaki, 2000).

Platelet-derived growth factor B (PDGFB) is another critical factor that promotes the recruitment and proliferation of vascular cells (Yancopoulos et al, 2000). The PDGF signalling indirectly regulates angiogenesis. Platelet-derived growth factor receptor $\beta$ $(\operatorname{PDGFR} \beta)$ can induce the transcription and secretion of VEGF. The PDGFB and its receptors (PDGFR) are expressed in several human cancers, such as gliomas, breast cancer, colorectal cancer, and myelomonocytic leukaemia (Yu et al, 2003). The PDGFR $\beta$ and PDGFB are expressed in meningiomas, and their overexpression correlates with the WHO grade (Wang et al, 1990; Yang, 2001).

Several therapeutic agents that specifically target the angiogenic pathway, such as sunitinib and tandutinib, have entered clinical development. Both compounds are tyrosine kinase inhibitors, but while sunitinib inhibits at least eight receptor protein tyrosine kinases, including $\mathrm{KDR}$ and $\operatorname{PDGFR} \beta$ (Mendel et al, 2003), tandutinib only acts on $\operatorname{PDGFR} \beta$, Fms-like tyrosine kinase 3 (FLT3), and c-Kit (Kelly et al, 2002). Sunitinib is used to treat 
metastatic renal cell cancer and gastrointestinal stromal tumours (Motzer et al, 2006), and tandutinib is in early-phase clinical evaluation for acute myeloid leukaemia (Cheng and Paz, 2008).

Recently, Liu et al (2010) demonstrated that gambogic acid inhibits cell migration by suppressing PDGFR $\beta$ tyrosine phosphorylation. Gambogic acid is the major active compound in gamboge, a resin from Garcinia hanburyi. Gambogic acid has potent apoptotic activity against several cancer cell lines in vitro and in vivo, including glioblastoma cell lines (Gu et al, 2008; Qiang et al, 2008).

In this study, we analysed the expression of VEGFA, KDR, PDGFB, and PDGFR $\beta$ in vitro and in vivo using quantitative real-time PCR (qRT-PCR) and the TaqMan Protein Assay. We examined the biological significance of VEGFA signalling through PDGFR $\beta$ by comparing the effects of VEGFA and PDGFB on meningioma cell proliferation and PDGFR $\beta$ tyrosine phosphorylation. We also determined the effects of gambogic acid and two tyrosine kinase inhibitors of PDGFR $\beta$ (sunitinib and tandutinib) on meningiomas in vitro.

\section{MATERIALS AND METHODS}

\section{Tumour specimens and cell culture}

The meningioma surgical specimens, arachnoidea, and dura were obtained from the Neurosurgical Department of the University of Tuebingen according to the guidelines of the ethics committee. The primary cultures were established from tumour tissue samples within $30 \mathrm{~min}$ of surgical removal. Samples were washed in phosphate-buffered saline (PBS), reduced, passed through a filter, and placed in Dulbecco's modified Eagle's medium (DMEM) supplemented with $10 \%$ fetal bovine serum (FBS) and $0.1 \%$ $10 \mathrm{mg} \mathrm{ml}^{-1}$ gentamycin (Invitrogen, Grand Island, NY, USA). The cells were plated in $25-\mathrm{mm}^{2}$ tissue culture flasks and incubated at $37^{\circ} \mathrm{C}$ in a humidified atmosphere with $5 \% \mathrm{CO}_{2}$. The medium was changed every 3-4 days, and the cultures were split with $600 \mu \mathrm{l}$ Accutase (PAA, Pasching, Austria). The viable cells were stored in liquid nitrogen in $90 \%$ medium $/ 10 \%$ dimethyl sulphoxide (DMSO). To verify the presence of tumour cells, the primary meningioma cultures were tested immunocytochemically for the expression of epithelial membrane antigen and vimentin. Both proteins are expressed in most meningiomas. The cells were also tested for the expression of CD34, an endothelial cell marker. The malignant meningioma IOMM-Lee cell line was a kind gift from A Lal (Department of Neurological Surgery, University of California, San Francisco, CA, USA). The IOMM-Lee cell line was tested using cytogenic characterisation. The human umbilical vein endothelial cells (HUVECs) (Genlantis + Cell Applications, Inc., San Diego, CA, USA) were cultured in endothelial cell growth medium (Genlantis, San Diego, CA, USA). The human prenatal neural cells (HNCs; dv Biologics, Costa Mesa, CA, USA) were cultured in Neurobasal A medium supplemented with $\mathrm{B} 27$ and $10 \mathrm{ng} \mathrm{ml}^{-1} \mathrm{FGF}$ basic (Invitrogen). The human adult mesothelial cells (HMCs; Zen-Bio, Research Triangle Park, NC, USA) were cultured in mesothelial cell growth medium (MSO-1; Zen-Bio).

\section{TaqMan protein assays}

The following biotinylated antibodies (R\&D Systems, Minneapolis, MN, USA) were used: VEGFA (BAF293), KDR (BAF357), PDGFB (BAF220), and PDGFR $\beta$ (BAF385). Phospho-PDGFR $\beta$ (AF1767) and phospho-KSR (AF1766) were labelled with biotin using the Biotin-XX Microscale Protein Labelling Kit (Invitrogen, Carlsbad, CA, USA) according to manufacturer's instructions. The biotinylated antibodies were labelled with the TaqMan Protein Assay Open Kit (Applied Biosystems, Foster City, CA, USA) as per manufacturer's instructions. The specificity of each assay was determined using the recombinant proteins VEGFA, PDGFB (Invitrogen Inc.), KDR, and PDGFR $\beta$ (R\&D Systems). Applied Biosystems recommends $\Delta \mathrm{Ct}$ values for recombinant proteins greater than 5. All $\Delta \mathrm{Ct}$ values for the above-mentioned assays were greater than 5 (VEGFA $\triangle \mathrm{Ct}=8.32$; $\mathrm{KDR} \quad \Delta \mathrm{Ct}=7.13$; PDGFB $\Delta \mathrm{Ct}=8.44$; and $\mathrm{PDGFR} \beta \Delta \mathrm{Ct}=5.17)$. The assays for phospho$\operatorname{PDGFR} \beta$ and phospho-KDR consisted of probe A PDGFR $\beta$ and probe $\mathrm{B}$ phospho-PDGFR $\beta$ and probe $\mathrm{A}$ KDR and probe $\mathrm{B}$ phospho-KDR, respectively. The specificity for phosphorylated PDGFR $\beta$ and KDR was determined using the recombinant proteins for $\operatorname{PDGFR} \beta$ and $\mathrm{KDR}$, which the respective assay could not detect.

The total meningioma protein in vitro was isolated directly from primary cell cultures before being split using the PARIS kit (Ambion, Inc., Austin, TX, USA). In vivo meningioma and dura proteins were isolated from fresh tissue using the Protein Quant Sample Lysis kit (Applied Biosystems) according to manufacturer's protocol. A two-fold serial dilution was prepared according to manufacturer's protocol with a cell lysate input per well of $5 \mu \mathrm{g}$ for meningiomas and dura. Total human brain protein (Biochain, Hayward, CA, USA) was used as a reference with an input amount of $25 \mu \mathrm{g}$. A TaqMan Protein Assay was performed using the TaqMan Protein Assay Core Reagents Kit with Master Mix (Applied Biosystems) according to manufacturer's instructions. qRT-PCR was performed on the StepOne Real-Time PCR System (Applied Biosystems) using the standard instrument protocol for the TaqMan Protein Assay. The data were analysed using the ProteinAssist Software 1.0 (Applied Biosystems), which uses the $\Delta \mathrm{Ct}^{2}$ method to calculate relative protein expression between untreated controls and treated samples. The sample dilutions were assayed, and the resulting Ct values were normalised to the sample input, which requires accurate protein quantitation. Every 48-well plate included a no-protein control (NPC) to calculate the $\Delta \mathrm{Ct}$ values (Ct value (sample) - Ct value (NPC)). Then, a linear range was generated for each sample, and a $\Delta \mathrm{Ct}$ threshold was designated. The fold change between samples was calculated between the crossover points of each linear trend line at the $\Delta \mathrm{Ct}$ threshold.

\section{RNA isolation and reverse transcription}

Total meningioma RNA was isolated in vitro directly from primary cell cultures before being split. Meningioma, arachnoidea, and dura RNA were isolated in vivo from fresh tissue using the PARIS kit (Ambion, Inc.) according to manufacturer's protocol. The RNA was treated with DNAfree (Ambion, Inc.) to remove residual genomic DNA. The RNA concentration and 260/280 absorbance ratios were measured in triplicate on an Eppendorf Biophotometer (Eppendorf, Hamburg, Germany). The integrity of the RNA samples was confirmed by electrophoresis on a $2 \%$ SYBR Green agarose gel (Invitrogen Inc.). The criteria for the inclusion of RNA samples were a 260/280 ratio of $\sim 2(1.9-2.2)$ and a $28 \mathrm{~S} / 18 \mathrm{~S}$ ratio of $\geqslant 1.7$. The probes were stored at $-80^{\circ} \mathrm{C}$ until use.

For normal brain samples, FirstChoice Human Brain Reference RNA (Ambion, Inc.), which pools RNA from various donors and several regions of the brain, was used. The RNA samples were treated with DNAfree (Ambion Inc.). The total RNA $(1 \mu \mathrm{g})$ was reverse transcribed to cDNA using the High-Capacity RNA-tocDNA Kit (Applied Biosystems) in $20 \mu \mathrm{l}$ according to manufacturer's protocol.

\section{Quantitative real-time PCR}

TaqMan qRT-PCR was performed in triplicate in 48-well reaction plates with StepOne (Applied Biosystems). Each reaction contained $1 \mu \mathrm{l}$ of cDNA ( $\left.5 \mathrm{ng} \mu \mathrm{l}^{-1}\right)$ in $20 \mu \mathrm{l}$ of reaction mix, containing $10 \mu \mathrm{l}$ of TaqMan Gene Expression Master Mix (Applied Biosystems) and $1 \mu \mathrm{l}$ of TaqMan Gene Expression Assay (Applied Biosystems). 
The following TaqMan Gene Expression primers were used: VEGFA (Hs99999070_m1), KDR (Hs00911700_m1), PDGFB (Hs00234042_m1), and PDGFRB (Hs00387364_m1). All primers span an exon junction and will not detect genomic DNA. The cycling conditions were as follows: an initial hold at $95^{\circ} \mathrm{C}$ for $10 \mathrm{~min}, 95^{\circ} \mathrm{C}$ for $15 \mathrm{~s}$, and $60^{\circ} \mathrm{C}$ for $1 \mathrm{~min}$ for 40 cycles.

Reverse transcriptase-negative controls and no-template controls (without cDNA) were included. RPL37A (Hs01102345_m1), which is the optimal reference for meningiomas and control tissues (Pfister et al, 2011), was used as the reference gene for relative quantification. The data were collected and analysed quantitatively using StepOne, v2.2 (Applied Biosystems). The relative gene expression data were analysed using the $2^{-\Delta \Delta \mathrm{Ct}}$ method (Erickson et al, 2007).

\section{Immunohistochemistry}

Four-micron sections that contained human meningiomas were cut from formalin-fixed paraffin-embedded tissue blocks. The slides were deparaffinised in a series of histolene (Engelbrecht, Edermuende, Germany) and alcohol solutions. The Vectastain Elite Universal Kit (Vector Laboratories, Burlingame, CA, USA) was used according to manufacturer's protocol. Briefly, the slides were treated with an antigen unmasking solution (citrate buffer, $\mathrm{pH}$ 6.0; $94{ }^{\circ} \mathrm{C} ; 30 \mathrm{~min}$ ), rinsed with $\mathrm{PBS}$, and bathed in $3 \% \mathrm{H}_{2} \mathrm{O}_{2}$ for $10 \mathrm{~min}$, followed by blocking with avidin/biotin (Vector Laboratories).

The slides were incubated overnight at $4{ }^{\circ} \mathrm{C}$ with a primary VEGFA rabbit polyclonal antibody (sc-152; Santa Cruz, Santa Cruz, CA, USA) at 1:60, a KDR rabbit polyclonal antibody (Ab2349; Abcam, Cambridge, MA, USA) at 1:100, a PDGFB rabbit polyclonal antibody (sc-127; Santa Cruz) at $1: 100$, or a PDGFR $\beta$ rabbit polyclonal antibody (sc-339; Santa Cruz) at $1: 200$. Next, the slides were washed three times with PBS, a biotinylated secondary antibody was applied, and a premixed avidin-biotin-peroxide complex was added (ABC; Vector Laboratories). The stains were developed with Vector Novared (Vector Laboratories). The positive controls were selected for each specimen as follows: VEGFA + KDR (human kidney), PDGFR $\beta$ (human placenta), and PDGFB (human pancreas). The negative control slides were incubated either without primary antibody or with a blocking peptide. The sections were counterstained with haematoxylin and examined using light microscopy. The immunohistochemical samples were graded from $0 \%$ to $100 \%$ based on the percentage of cells that were positive relative to the total tissue.

\section{Growth factors, inhibitors, and drugs}

VEGF $_{165}$ (VEGFA, PHC9391; Invitrogen Inc.) was reconstituted in sterile distilled water, aliquoted, and stored at $-20^{\circ} \mathrm{C}$ until use. PDGF-BB (PDGFB, PHG0041; Invitrogen Inc.) was reconstituted in $100 \mathrm{~mm}$ acetic acid and $0.1 \%$ BSA, aliquoted, and stored at $-20^{\circ} \mathrm{C}$ until use. The VEGFR2 (KDR) kinase inhibitor VI (Ki8751) (676484; Merck, Darmstadt, Germany) inhibits KDR with an $\mathrm{IC}_{50}$ of $0.9 \mathrm{~nm}$ and has no effect on PDGFR $\beta$ at concentrations as high as $10 \mu \mathrm{M}$. PDGFR tyrosine kinase inhibitor III (521232; Merck) inhibits $\mathrm{PDGFR} \beta$ with an $\mathrm{IC}_{50}$ of $80 \mathrm{~nm}$ with no inhibitory effect on KDR. Both inhibitors were dissolved in DMSO (Sigma-Aldrich, St Louis, MO, USA) and stored at $-20^{\circ} \mathrm{C}$. Sunitinib malate (SU-11248, Sutent) and gambogic acid were obtained from Santa Cruz, and tandutinib (MLN518) was purchased from Selleck Chemicals (Houston, TX, USA). The stock solutions of sunitinib, tandutinib, and gambogic acid were dissolved in DMSO, stored at $-20^{\circ} \mathrm{C}$, and diluted in fresh medium immediately before use.

\section{Proliferation assay}

The IOMM-Lee cells and primary meningioma cells in mid-log phase were seeded onto 24-well culture plates in DMEM containing
$10 \% \mathrm{FBS}$ for $24 \mathrm{~h}$. Subsequently, the cells were treated with increasing concentrations of VEGFA $\left(0,5,10,20,50\right.$, and $\left.100 \mathrm{ng} \mathrm{ml}^{-1}\right)$ in serumfree medium for $4 \mathrm{~h}$. After $3 \mathrm{~h}$ of treatment, 5-Bromo-2'-deoxy-uridine (BrdU) was added to each well $(1: 1000)$. After incubation, BrdU was detected using the BrdU Labelling and Detection Kit II (Roche, Mannheim, Germany) according to manufacturer's protocol. The cell number was evaluated under a light microscope.

\section{GAP assay}

Primary meningioma cells $\left(0.3 \times 10^{6}\right.$ cells per $\left.\mathrm{ml}\right)$ were seeded onto 24-well tissue culture dishes using the Radius 24-Well Cell Migration Assay (Cell Biolabs, Inc., San Diego, CA, USA) according to manufacturer's instructions. After $24 \mathrm{~h}$ of incubation to allow spreading, the gel was removed. The compounds were added in a medium that contained 10\% FBS, and the cells were incubated for $24 \mathrm{~h}$ with various concentrations of sunitinib, tandutinib, and gambogic acid $\left(0.125-10 \mu \mathrm{g} \mathrm{ml}^{-1}\right)$ to determine their effect on cell migration. The meningioma cell migration was observed and photographed under an inverted microscope before and after $24 \mathrm{~h}$ of inhibition with sunitinib, tandutinib, or gambogic acid. The cells were analysed using CellProfiler (www.cellprofiler.org) (Carpenter et al, 2006).

\section{Statistical analysis}

Statistical analysis was performed with GraphPad Prism, V5.03 (GraphPad Software, La Jolla, CA, USA). All results are expressed as mean values \pm standard deviation (s.d.). Statistical comparisons between two groups were made using the Mann-Whitney test. For statistical comparisons between a group and the human brain reference, the Wilcoxon signed-rank test was used. Significant differences between sets of data were determined using a paired $t$-test. The level of significance was set at $P<0.05$. All tests were two-sided.

\section{RESULTS}

\section{Elevated PDGFR $\beta$ expression in meningiomas}

The RNA and protein expression was measured in meningiomas in vitro and in vivo (Table 1). The RNA expression was quantified using qRT-PCR with RPL37A for normalisation. The protein levels were measured with a TaqMan Protein Assay. The human brain was used as a reference. Only three samples of arachnoidea, the cap cells from which meningiomas originate, were obtained. Due to the small sample size and the structure of the arachnoidea, only a small amount of RNA and protein was isolated. The RNA and protein levels of several angiogenesis genes in the arachnoidea and

Table I The number of meningiomas used for the in vivo and in vitro experiments

\begin{tabular}{|c|c|c|c|c|}
\hline & \multicolumn{2}{|c|}{ RNA } & \multicolumn{2}{|c|}{ Protein } \\
\hline & In vivo & In vitro & In vivo & In vitro \\
\hline Arachnoidea & 3 & - & 3 & - \\
\hline Dura & 10 & - & 6 & - \\
\hline Meningioma WHO ^| & 28 & 39 & 17 & 17 \\
\hline Meningioma WHO ॥ & 21 & 34 & 17 & 17 \\
\hline Meningioma WHO III & 3 & 5 & 3 & 5 \\
\hline
\end{tabular}

Abbreviation: $\mathrm{WHO}=$ World Health Organisation. In vivo RNA and protein were isolated directly from fresh surgical specimen. For the in vitro RNA and protein isolation, the surgical specimen were processed and cultured, and the RNA and protein were isolated before the cells were split. The RNA and protein were isolated from human dura directly due to the difficulties in handling. 
dura were similar, with the exception of KDR, which was significantly higher in arachnoidea $(P=0.002)$. Thus, we chose to measure the gene expression in the dura, from which ample RNA and protein could be isolated. Due to the small number of arachnoidea samples, the expression of angiogenesis genes in meningiomas was compared with the expression in dura to detect significant changes in expression levels, except for KDR. All results are expressed as the relative gene expression levels (RQ) to brain $\left(\mathrm{RQ}_{\text {Brain }}=1\right)$ for RNA or as the fold change with brain as reference (fold change $\mathrm{Brain}_{\mathrm{B}}=1$ ) for protein.

The PDGFR $\beta$ RNA and protein expression was significantly higher in meningiomas compared with the brain $(P<0.0001)$ (Figure 1A). The PDGFR $\beta$ RNA expression in vitro was significantly decreased in WHO ${ }^{\circ} \mathrm{III}\left(P_{\mathrm{WHO}}{ }^{\circ} \mathrm{I} v s\right.$ WHO ${ }^{\circ} \mathrm{III}=0.0198$ and $P_{\text {WHO }}{ }^{\circ}$ II $v s$ WHO $\left.{ }^{\circ} \mathrm{III}=0.0004\right)$, but there was no difference between WHO ${ }^{\circ} \mathrm{I}$ and ${ }^{\circ} \mathrm{II}$. The in vivo RNA expression of PDGFR $\beta$ was significantly decreased in meningiomas compared with dura $(P=0.0014)$ but displayed no significant changes between WHO grades. In contrast to the in vitro RNA levels, the in vitro protein expression of PDGFR $\beta$ was significantly decreased in dura compared with meningioma $(P=0.042)$. The PDGFR $\beta$ RNA and protein levels in vitro were significantly higher than those detected in vivo $\left(P_{\mathrm{RNA}}=0.0002 ; P_{\text {Protein }}=0.0045\right)$.

\section{Most meningiomas displayed no KDR protein expression}

The KDR RNA and protein expression was significantly elevated in arachnoidea compared with dura $\left(P_{\mathrm{RNA}}=0.002 ; P_{\text {Protein }}=0.0167\right)$ (Figure 1B). In addition, the KDR levels were higher in dura compared with the brain $\left(P_{\mathrm{RNA}}=0.002 ; P_{\text {Protein }}=0.0156\right)$. In contrast, the KDR RNA and protein expression in meningiomas was significantly decreased $\left(P_{\mathrm{RNA}}=0.001 ; P_{\text {Protein }}=0.0014\right)$. In fact, KDR could not be detected in most meningiomas. Only 4 of 38 (10.3\%) primary meningioma cell cultures displayed positive KDR protein expression (Figure 1C). In all, 8 of the $37(21.6 \%)$ meningiomas that were isolated directly from fresh surgical specimens were KDR positive. The KDR RNA expression was extremely low in most meningiomas $\left(\operatorname{median}_{\text {in }}\right.$ vitro $=0.17$; median $\left._{\text {in vivo }}=0.28\right)$. Only five in vitro $(6.4 \%)$ and nine in vivo (17.3\%) meningiomas displayed an RQ of $>0.5$. The KDR expression was two-fold higher in meningiomas in vivo, but a significant difference was only displayed between the in vivo and in vitro RNA levels $(P=0.0043)$. There were no significant differences in the expression levels between WHO grades. For comparison, the RNA and protein expression levels of PDGFR $\beta$ and KDR in eight cancer cell lines were determined (data not shown). The PDGFR $\beta$ expression was on average 97\% lower in cancer cell lines compared with brain expression, and KDR expression was on average $15 \%$ higher.

\section{Broad distribution of VEGFA expression and low PDGFB expression in meningiomas}

VEGFA RNA in vivo and in vitro was significantly downregulated in meningiomas compared with arachnoidea and dura (arachnoidea: $P_{\text {in }}$ vitro $=0.0346 ; P_{\text {in }}$ vivo $=0.0331$; dura: $P_{\text {in }}$ vitro $=0.012$; $P_{\text {in vivo }}=0.0023$ ) (Figure $\left.1 \mathrm{D}\right)$. In contrast, the in vitro VEGFA protein expression was significantly higher in meningiomas compared with dura $(P=0.034)$. In addition, the VEGFA expression in meningiomas displayed a broad distribution, especially in vivo. For the in vivo RNA expression, the minimum was 0.02 and the maximum was 132.5 with a median of 0.725 . In vitro, the lowest VEGFA expression was 0.22 and the highest expression was 38.34 with a median of 1.42 . For the in vivo protein expression, the minimum was 0.001 and the maximum was 80 with a median of 2.6. The lowest VEGFA expression in vitro was 0.029 and the highest expression was 65 with a median of 0.92 .
The PDGFB RNA and protein levels were significantly downregulated in meningiomas compared with dura (RNA: $P_{\text {in vitro }}=0.0002 ; P_{\text {in vivo }}=0.0076$; protein: $P_{\text {in vitro }}=0.003$; $P_{\text {in vivo }}=0.0082$ ), as shown in Figure $1 \mathrm{E}$. There were no significant differences in expression levels between WHO grades.

\section{Immunohistochemical staining of angiogenetic proteins}

Immunohistochemistry was performed using 54 surgical human meningioma specimens that included - $28 \mathrm{WHO}{ }^{\circ} \mathrm{I}, 21 \mathrm{WHO}{ }^{\circ} \mathrm{II}$, and 5 WHO ${ }^{\circ} \mathrm{III}$ meningiomas. Figure $2 \mathrm{~A}$ shows a representation of the staining in a negative control (A), a positive control (kidney) for VEGFA (B), positive VEGFA expression in a meningioma (C), a positive control (kidney) for KDR (D), positive KDR expression in a meningioma (E), negative KDR expression in a meningioma (F), a positive control (placenta) for $\operatorname{PDGFR} \beta(\mathrm{G})$, and positive PDGFR $\beta$ expression in two meningiomas $(\mathrm{H}+\mathrm{I})$. All angiogenetic proteins displayed cytoplasmic and membranous staining in neoplastic cells. Expression of KDR and PDGFR $\beta$ was also found in blood vessels. Figure 2B-E shows the expression of angiogenetic proteins based on the percentage of cells that were positive relative to the total tissue sample.

All meningiomas stained positive for VEGFA and PDGFR $\beta$. The median percentage of PDGFR $\beta$-positive cells in meningiomas was $20 \%$ (range $2-80 \%$ ). As shown in Figure 2C, PDGFR $\beta$ expression differed between grades $\left(P_{\mathrm{WHO}}{ }^{\circ} \mathrm{I} v s\right.$ WHO ${ }^{\circ} \mathrm{II}=0.0426$; $P_{\mathrm{WHO}}{ }^{\circ} \mathrm{II} v s$ WHO $\left.{ }^{\circ} \mathrm{II}=0.0315\right)$. The median percentage of VEGFA-positive cells was 30\% (range 2-90\%). The expression in meningiomas did not differ between WHO ${ }^{\circ} \mathrm{I}$ and WHO ${ }^{\circ} \mathrm{II}$. In contrast, VEGFA expression was higher in grade WHO ${ }^{\circ}$ III $v s$ grade WHO ${ }^{\circ}$ II meningiomas $(P=0.02)$ (Figure 2D).

Forty-seven meningiomas (87\%) were positive for KDR with a median percentage of $2.5 \%$. Most meningiomas (67\%) showed low KDR expression with up to $5 \%$ positive cells. Eleven meningiomas (20\%) demonstrated $10-30 \%$ positive staining. Expression of KDR was not significantly different between the WHO grades (Figure 2E).

Fifty-three meningiomas (98\%) were positive for PDGFB (median percentage $20 \%$ and maximum $90 \%$ ). There were no differences in PDGFB expression between the WHO grades.

\section{Proliferative response to exogenous VEGFA in meningiomas}

To investigate the biological significance of the elevated PDGFR $\beta$ expression and the mostly non-expression of KDR in meningiomas IOMM-Lee cells, a malignant proliferating meningioma cell line, were cultured with increasing amounts $(0,5,10,20,50$, and $100 \mathrm{ng} \mathrm{ml}^{-1}$ ) of VEGFA and PDGFB for $4 \mathrm{~h}$ in serum-free medium. As shown in Figure $3 \mathrm{~A}$, cell proliferation was significantly increased after treatment with $10 \mathrm{ng} \mathrm{ml}^{-1}$ VEGFA ( $+42 \%$ compared with control conditions, $P<0.05), 20 \mathrm{ng} \mathrm{ml}^{-1}$ VEGFA $(+87.4 \%$ compared with control conditions, $P<0.005)$, $50 \mathrm{ng} \mathrm{ml}^{-1}$ VEGFA ( $+94.6 \%$ compared with control conditions, $P<0.005)$, and $100 \mathrm{ng} \mathrm{ml}^{-1}$ VEGFA $(+99 \%$ compared with control conditions, $P<0.001)$. The control cells were also incubated with PDGFB. As shown in Figure 3B, cell proliferation was similarly increased after treatment with $10 \mathrm{ng} \mathrm{ml}^{-1} \mathrm{PDGFB}$ ( $+46.2 \%$ compared with control conditions, $P<0.05), 20 \mathrm{ng} \mathrm{ml}^{-1}$ PDGFB $(+71.2 \%$ compared with control conditions, $P<0.005)$, and $50 \mathrm{ng} \mathrm{ml}^{-1}$ PDGFB ( $+87.5 \%$ compared with control conditions, $P<0.005)$. After treatment with $100 \mathrm{ng} \mathrm{ml}^{-1}$ PDGFB, proliferation decreased compared with treatment with $50 \mathrm{ng} \mathrm{ml}^{-1}$ PDGFB $(+71.3 \%$ compared with control conditions, $P<0.005)$.

To determine if these results also apply to benign meningiomas with low proliferation, two primary cell cultures of meningothelial meningiomas were treated as described. As shown in Figure 3C, the mean proliferation without growth factors was $5.4 \pm 1.7 \%$. 

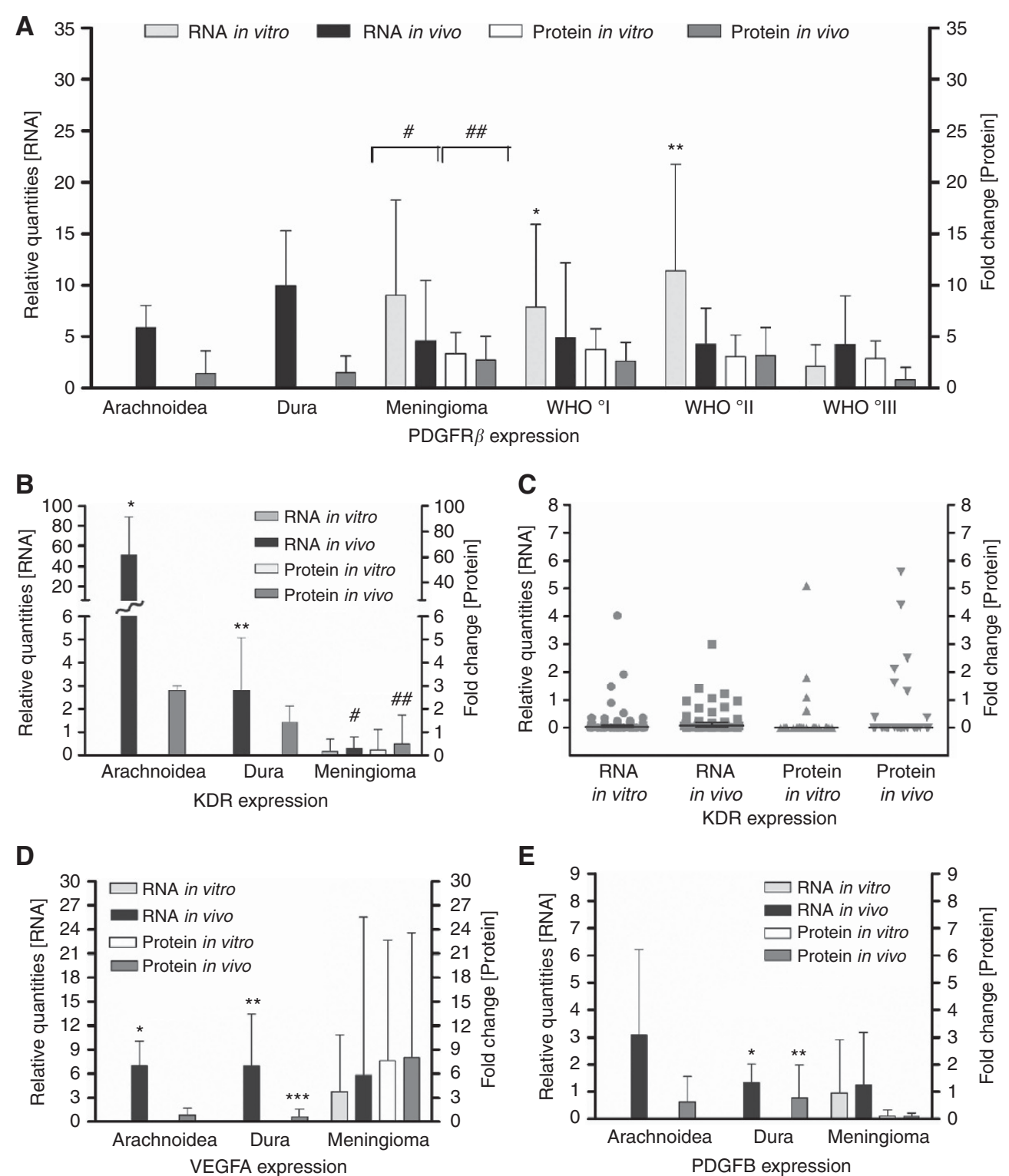

Figure I The in vitro and in vivo RNA and protein expression of angiogenetic proteins in meningiomas and dura. Expression of RNA was quantified using qRT-PCR with RPL37A for normalisation. The protein levels were measured using the TaqMan Protein Assay. The data for RNA are expressed as the relative gene expression level $(R Q)$ compared with the brain $\left(R Q_{\text {Brain }}=1\right)$. The data for protein are expressed as fold change, with the brain as the reference. (A) The PDGFR $\beta$ RNA and protein expression was significantly higher in meningiomas compared with the brain. The in vitro PDGFR $\beta$ RNA

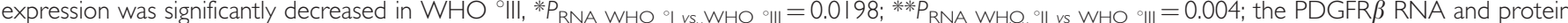
levels in vitro were significantly higher compared with those in vivo. ${ }^{\#} P_{\mathrm{RNA}}$ in vitro vs in vivo $=0.0002 ;{ }^{\# \#} P_{\text {Protein in vitro vs in vivo }}=0.045$. The bars represent the mean \pm s.d. (B) The KDR RNA and protein expression levels were significantly elevated in arachnoidea compared with dura, $* P_{\mathrm{RNA}}=0.002$ *** $P_{\text {Protein }}=0.0167$. In meningiomas, the KDR RNA and protein expression levels were significantly decreased, ${ }^{\# \text { RNA }}=0.001 ;{ }^{\# \#} P_{\text {Protein }}=0.0014$. (C) Most

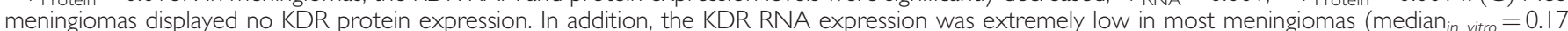
median $_{\text {in vivo }}=0.28$ ). The symbols represent single data points. The horizontal bars represent the median. (D) The VEGFA RNA was significantly downregulated in vivo and in vitro in meningiomas compared with arachnoidea (* $P=0.033 \mathrm{I})$ and dura $(* * P=0.0023)$. In contrast, the VEGFA protein expression in vitro was significantly higher in meningiomas compared with dura (**** $=0.034)$. (E) The PDGFB RNA and protein levels were significantly downregulated in meningiomas compared with dura, $* P_{\mathrm{RNA}}=0.0076 ; * * P_{\text {Protein }}=0.0082$.

Cell proliferation was significantly increased after treatment with $20 \mathrm{ng} \mathrm{ml}^{-1}$ VEGFA ( $+100 \%$ compared with control conditions, $P<0.05), 50 \mathrm{ng} \mathrm{ml}^{-1}$ VEGFA $(+126.2 \%$ compared with control conditions, $P<0.005)$, and $100 \mathrm{ng} \mathrm{ml}^{-1}$ VEGFA $(+114.7 \%$ compared with control conditions, $P<0.001)$. Treatment with PDGFB significantly increased proliferation in benign meningiomas after treatment with $10 \mathrm{ng} \mathrm{ml}^{-1}$ PDGFB $(+84.7 \%$ compared with control conditions, $P<0.05), \quad 20 \mathrm{ng} \mathrm{ml}^{-1}$ PDGFB $\quad(+99.1 \%$ compared with control conditions, $P<0.005)$, and $50 \mathrm{ng} \mathrm{ml}^{-1}$ PDGFB $(+134.4 \%$ compared with control conditions, $P<0.005)$. After treatment with $100 \mathrm{ng} \mathrm{ml}^{-1}$ PDGFB proliferation slightly decreased compared with treatment with $50 \mathrm{ng} \mathrm{ml}^{-1}$ PDGFB $(+130.8 \%$ compared with control conditions, $P<0.005)$, as shown in Figure 3D.

To evaluate the functional effect of these findings, PDGFR $\beta$ and KDR were inhibited with an anti-PDGFR $\beta$ neutralisation antibody 
A

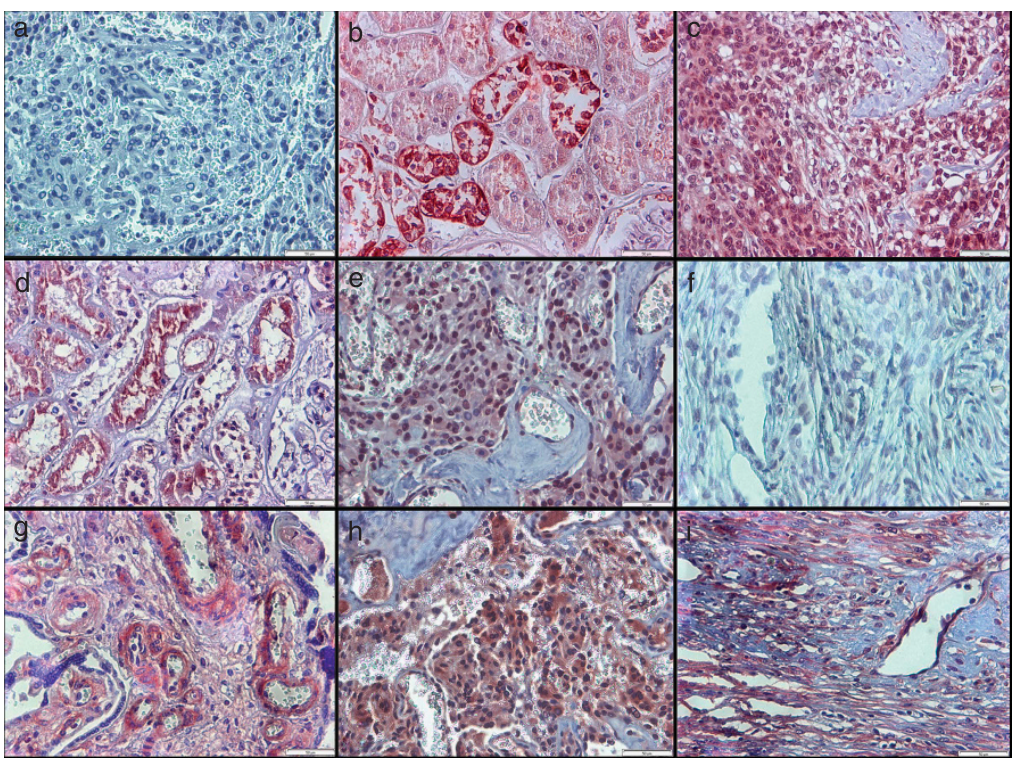

B
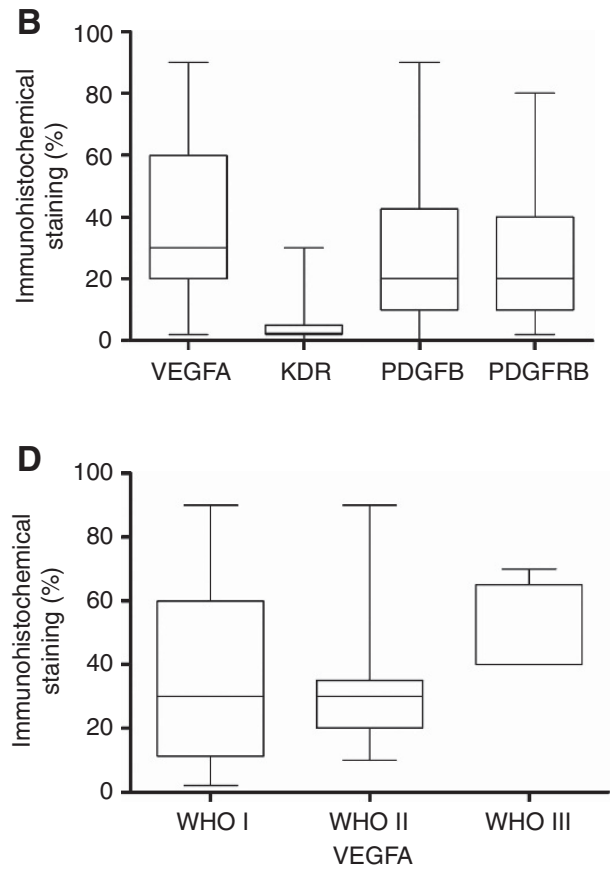
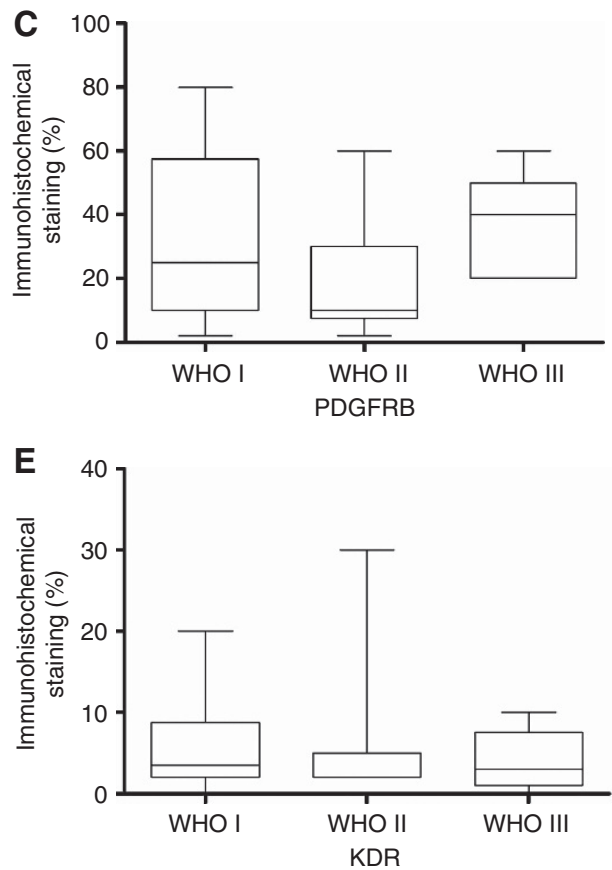

Figure 2 Immunohistochemical staining of angiogenic proteins in meningiomas. The paraffin-embedded, formalin-fixed sections of meningiomas were stained with antibodies against VEGFA, KDR, PDGFB, and PDGFR $\beta$. Positive immunoreactivity appears as red staining (Vector NovaRed). The stains were graded from $0 \%$ to $100 \%$ based on the percentage of cells that were positive relative to the total tissue. (A) The panels are a representation of staining in a negative control (a), a positive VEGFA control (kidney) (b), positive VEGFA expression in a meningioma (c), a positive KDR control (kidney) (d), positive KDR expression in a meningioma (e), negative KDR expression in a meningioma ( $f$ ), a positive PDGFR $\beta$ control (placenta) (g), and positive PDGFR $\beta$

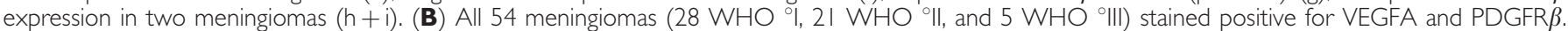
Forty-seven meningiomas (87\%) were positive for KDR with a median percentage of $2.5 \%$. (C) The PDGFR $\beta$ expression differed between grades $\left(P_{\mathrm{WHO}} \%\right.$ vs

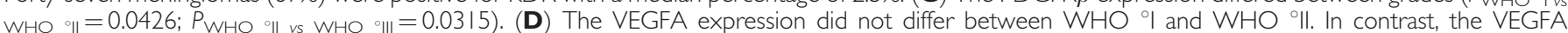
expression was higher in grade $\mathrm{WHO}{ }^{\circ}$ III vs grade $\mathrm{WHO}{ }^{\circ} \mathrm{Il}$ meningiomas $(P=0.02)$. (E) The $\mathrm{KDR}$ expression displayed no significant differences between WHO grades. The box plots represent maximum and minimum values with the median.

or a PDGFR $\beta$ tyrosine kinase inhibitor or an anti-KDR neutralisation antibody or a KDR tyrosine kinase inhibitor, respectively, before stimulation with VEGFA.

Pre-treatment with either $10 \mu \mathrm{g} \mathrm{ml}^{-1}$ anti-PDGFR $\beta$ neutralisation antibody or $2 \mu \mathrm{M} \operatorname{PDGFR} \beta$ tyrosine kinase inhibitor (PDGFR $\beta$-TK) for $1 \mathrm{~h}$ followed by incubation with $10 \mathrm{ng} \mathrm{ml}^{-1}$ VEGFA for $4 \mathrm{~h}$ resulted in a significant decrease in IOMM-Lee cell growth compared with VEGFA grown without pre-treatment
$(-38.7 \%$ after anti-PDGFR $\beta$ pre-treatment, $P<0.005$ and $-32.6 \%$ after PDGFR $\beta$-TK pre-treatment, $P<0.05$, Figure $3 \mathrm{E}$ ). In contrast, pre-treatment with either $10 \mu \mathrm{g} \mathrm{ml}^{-1}$ anti-KDR neutralisation antibody or $100 \mathrm{~nm}$ KDR tyrosine kinase inhibitor (KDR-TK) before incubation with VEGFA displayed no antiproliferating effect.

In addition, two benign meningiomas were pre-treated as described before and then incubated with $50 \mathrm{ng} \mathrm{ml}^{-1}$ VEGFA 
A
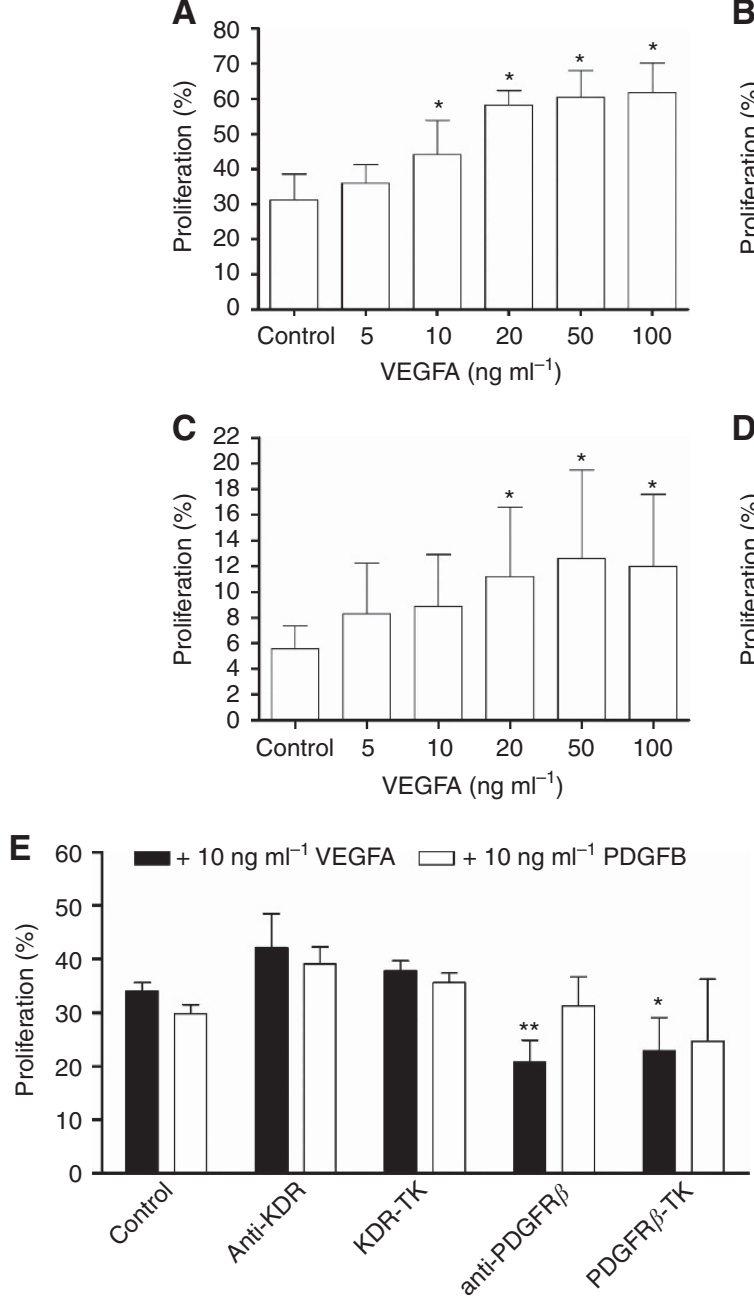

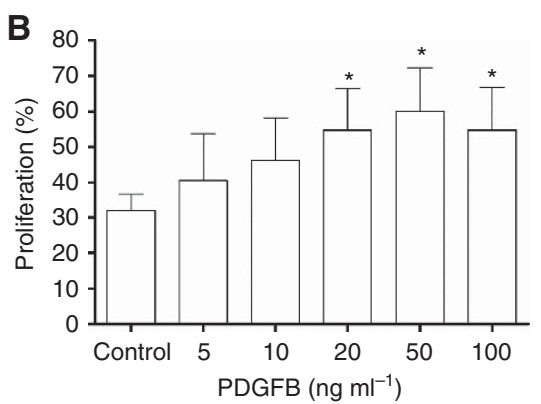

D


Figure 3 The exposure to VEGFA increased proliferation in meningiomas in vitro: Proliferation was determined on the basis of the malignant meningioma cell line IOMM-Lee $(\mathbf{A}$ and $\mathbf{B})$ and two benign meningiomas $(\mathbf{C}$ and $\mathbf{D})$. The cells were incubated for $4 \mathrm{~h}$ with serum-free medium and fresh growth factor. The control represents proliferation independent of supplemented growth factor. Proliferation was measured using a BrdU assay. (A and C) VEGFA (B and D) PDGFB. (E) The inhibition of PDGFR $\beta$ decreased the VEGFA-induced proliferation. The IOMM-Lee cells were pre-treated for I h with $10 \mu \mathrm{g} \mathrm{ml}^{-1}$ of either anti-KDR or -PDGFR $\beta$ neutralisation antibodies, $100 \mathrm{~nm}$ KDR tyrosine kinase inhibitor (KDR-TK) and $2 \mu \mathrm{M}$ PDGFR $\beta$ tyrosine kinase inhibitor (PDGFR $\beta$-TK), followed by either $10 \mathrm{ngml}^{-1}$ VEGFA or $10 \mathrm{ng} \mathrm{ml}^{-1}$ PDGFB for $4 \mathrm{~h}$. The control represents VEGFA- or PDGFB-induced proliferation. (F) The inhibition of PDGFR $\beta$ or KDR decreased VEGFA-induced proliferation in benign meningiomas. After pre-treatment, the cells were incubated with either $50 \mathrm{ng} \mathrm{ml}^{-1}$ VEGFA or $50 \mathrm{ng} \mathrm{ml}^{-1}$ PDGFB. The control represents VEGFA- or PDGFB-induced proliferation. The data shown are the mean number of proliferating cells \pm s.d. determined from five random fields from each of three independent experiments. $* P<0.05 ; * * P<0.005$.

for $4 \mathrm{~h}$, because the primary meningioma cell cultures displayed the highest proliferation effect after treatment with this growth factor concentration. Cell growth significantly decreased after the inhibition of PDGFR $\beta(-43.1 \%$ after anti-PDGFR $\beta$ pre-treatment, $P<0.05$ and $-54.2 \%$ after PDGFR $\beta$-TK pre-treatment, $P<0.05$; Figure 3F). The control cells were incubated with $50 \mathrm{ng} \mathrm{ml}^{-1}$ PDGFB. Cell proliferation significantly decreased after antiPDGFR $\beta$ pre-treatment $37.7 \%$ and decreased $44.4 \%$ after PDGFR $\beta$-TK pre-treatment $(P<0.05)$. In addition, meningioma cell growth significantly decreased after the inhibition of KDR and incubation with VEGFA $(-47.5 \%$ after anti-KDR pre-treatment, $P<0.05$ and $-48.1 \%$ after KDR-TK pre-treatment, $P<0.005)$.

\section{VEGFA induced PDGFR $\beta$ tyrosine phosphorylation}

To provide further evidence that PDGFR $\beta$ is stimulated by VEGFA, six randomly chosen primary meningioma cells (four WHO ${ }^{\circ} \mathrm{I}+$ two WHO $\left.{ }^{\circ} \mathrm{II}\right)$ were starved for $24 \mathrm{~h}$ in serum-free medium. The cells were stimulated with increasing amounts of either
VEGFA or PDGFB for $10 \mathrm{~min}$ at $37^{\circ} \mathrm{C}$. PDGFR $\beta$ expression and $\operatorname{PDGFR} \beta$ phosphorylation were measured with the TaqMan Protein Assay. The HUVEC was used as the control. PDGFR $\beta$ and KDR expression was determined in different cell types (Figure 4A). As expected, the HUVECs displayed high KDR and very low PDGFR $\beta$ expression. Because meningiomas are of mesenchymal origin cultured normal mesothelial cells (HMCs) were also examined. These cells showed both PDGFR $\beta$ and KDR expression. In contrast, HNCs displayed very low KDR expression and decreased PDGFR $\beta$ levels compared with the brain.

After the HUVECs were stimulated with VEGFA, the tyrosine phosphorylation of KDR was evaluated. The tyrosine phosphorylation of KDR reached a maximum with $10 \mathrm{ng} \mathrm{ml}^{-1}$ VEGFA and decreased with higher VEGFA concentrations (Figure 4B). The tyrosine phosphorylation level of $\operatorname{PDGFR} \beta$ was determined after stimulation with PDGFB, which was three-fold higher after stimulation with $10 \mathrm{ng} \mathrm{ml}^{-1}$ PDGFB.

All meningiomas tested displayed high $\operatorname{PDGFR} \beta$ expression, and KDR was not detectable. The PDGFR $\beta$ expression and PDGFR $\beta$ 



Figure 4 VEGFA stimulated PDGFR $\beta$ tyrosine phosphorylation is comparable to PDGFB in meningiomas in vitro. (A) PDGFR $\beta$ and KDR expression was compared between meningiomas, HUVECs, HNCs, and HMCs. The data are expressed as relative quantities $(R Q s)$ compared with the brain $(R Q B r a i n=0)$. The HUVECs were used as a PDGFR $\beta$-negative and KDR-positive control. (B) The tyrosine phosphorylation was determined in HUVECs as a control. The HUVECs were starved for $24 \mathrm{~h}$ with serum-free medium. The cells were stimulated with increasing concentrations of either VEGFA or PDGFB for 10 min at $37^{\circ} \mathrm{C}$. The tyrosine phosphorylation was measured using a TaqMan Protein Assay. The data are shown as the mean number of two independent experiments using different HUVEC cultures. (C and D) Six primary meningioma cell cultures were given the same treatment as the HUVECs. The PDGFR $\beta$ expression and PDGFR $\beta$ phosphorylation were determined. ${ }^{*} P<0.05 ;{ }^{\#} P<0.005$, compared with the respective unstimulated cells. The bars represent the mean \pm s.d.

phosphorylation were determined from VEGFA-treated primary meningioma cells. As shown in Figure 4C, the phosphorylation of PDGFR $\beta$ by VEGFA increased with increasing concentrations. The tyrosine phosphorylation level was three-fold higher after stimulation with $10 \mathrm{ng} \mathrm{ml}^{-1}$ VEGFA (fold change $=3.4 \pm 1.18$, $P<0.05)$ and doubled after stimulation with $20 \mathrm{ng} \mathrm{ml}^{-1}$ VEGFA (fold change $=6.1 \pm 3.62, P<0.05$ ). The tyrosine phosphorylation of PDGFR $\beta$ reached its maximum with $100 \mathrm{ng} \mathrm{ml}^{-1}$ VEGFA (fold change $=9.5 \pm 4.79, P<0.005$ ). The control cells were also stimulated with PDGFB. As shown in Figure 4D, the tyrosine phosphorylation of $\operatorname{PDGFR} \beta$ increased higher after stimulation with $5 \mathrm{ng} \mathrm{ml}^{-1}$ PDGFB (fold change $=3.1 \pm 1.75, P<0.05$ ) and $10 \mathrm{ng} \mathrm{ml}^{-1}$ PDGFB (fold change $=5.5 \pm 1.28, P<0.005$ ). After stimulation with $20 \mathrm{ng} \mathrm{ml}^{-1}$ PDGFB, the tyrosine phosphorylation of PDGFR $\beta$ was similar to VEGFA (fold change $=6.9 \pm 0.98$, $P<0.005)$. With $50 \mathrm{ng} \mathrm{ml}^{-1}$ PDGFB, the tyrosine phosphorylation of PDGFR $\beta$ reached its maximum (fold change $=11.9 \pm 3.43$, $P<0.005)$.

Gambogic acid, sunitinib, and tandutinib inhibit migration of primary meningioma cells

The Radius cell migration assay was used to examine the migration of six randomly chosen primary meningioma cells (four WHO ${ }^{\circ} \mathrm{I}+$ two WHO ${ }^{\circ} \mathrm{II}$ ) after treatment with the angiogenesis inhibitors sunitinib and tandutinib. Sunitinib is a tyrosine kinase inhibitor that inhibits at least eight receptor protein tyrosine kinases, including $\mathrm{KDR}$ and PDGFR $\beta$, at the same $\mathrm{IC}_{50}(10 \mathrm{nM})$ (Mendel et al, 2003). In contrast, tandutinib is a more selective tyrosine kinase inhibitor that does not inhibit $\mathrm{KDR}$ up to $\mathrm{IC}_{50}=30 \mu \mathrm{m}$ but affects PDGFR $\beta$ in vitro at $\mathrm{IC}_{50}=30 \mathrm{~nm}$ and in cellular assays at
$\mathrm{IC}_{50}=200 \mathrm{~nm}$ (Kelly et al, 2002). The effect of gambogic acid on meningioma cell migration was also examined. Gambogic acid inhibits the transferrin receptor with an $\mathrm{IC}_{50}$ of $1 \mu \mathrm{M}$, induces apoptosis and inhibits cell growth with an $\mathrm{EC}_{50}$ of $0.5-1.5 \mu \mathrm{M}$ (Kasibhatla et al, 2005).

Sunitinib, tandutinib, and gambogic acid suppressed cell migration (Figure 5A). With increasing doses of gambogic acid (b-i), meningioma cells became unable to close the uncoated gap in $24 \mathrm{~h}$. Figure 5B shows the dose-dependent inhibition of cell migration by meningiomas following incubation with $31.25-$ $2000 \mathrm{ng} \mathrm{ml}^{-1}$ gambogic acid. Cell migration was inhibited in a concentration-dependent manner with a mean of $9.3 \%$ for $31.25 \mathrm{ng} \mathrm{ml}^{-1}$ gambogic acid to $72.1 \%$ for $2000 \mathrm{ng} \mathrm{ml}^{-1}$ gambogic acid. Migration was suppressed by $50 \%$ on average with $1 \mu \mathrm{g} \mathrm{ml}^{-1}$ gambogic acid (1.6 nM). Sunitinib and tandutinib inhibited cell migration similar to gambogic acid. Migration was suppressed by $50 \%$ on average with $3.8 \mathrm{~nm}$ sunitinib and with $3.6 \mathrm{~nm}$ tandutinib (Supplementary material online).

\section{Gambogic acid inhibits tyrosine phosphorylation of PDGFR $\beta$}

Gambogic acid inhibits cell migration by suppressing PDGFR $\beta$ tyrosine phosphorylation, as demonstrated by Liu et al (2010). Thus, three randomly chosen primary meningothelial meningioma cells were pre-treated with increasing concentrations (0.125$2 \mathrm{ng} \mathrm{ml}^{-1}$ ) of gambogic acid for $1 \mathrm{~h}$. Then, cells were stimulated with either $100 \mathrm{ng} \mathrm{ml}^{-1}$ VEGFA or PDGFB for $10 \mathrm{~min}$ at $37^{\circ} \mathrm{C}$. $\operatorname{PDGFR} \beta$ expression and PDGFR $\beta$ phosphorylation were measured using a TaqMan Protein Assay. As shown in Figure 5C, gambogic acid inhibited the tyrosine phosphorylation of $\operatorname{PDGFR} \beta$ after 
A a
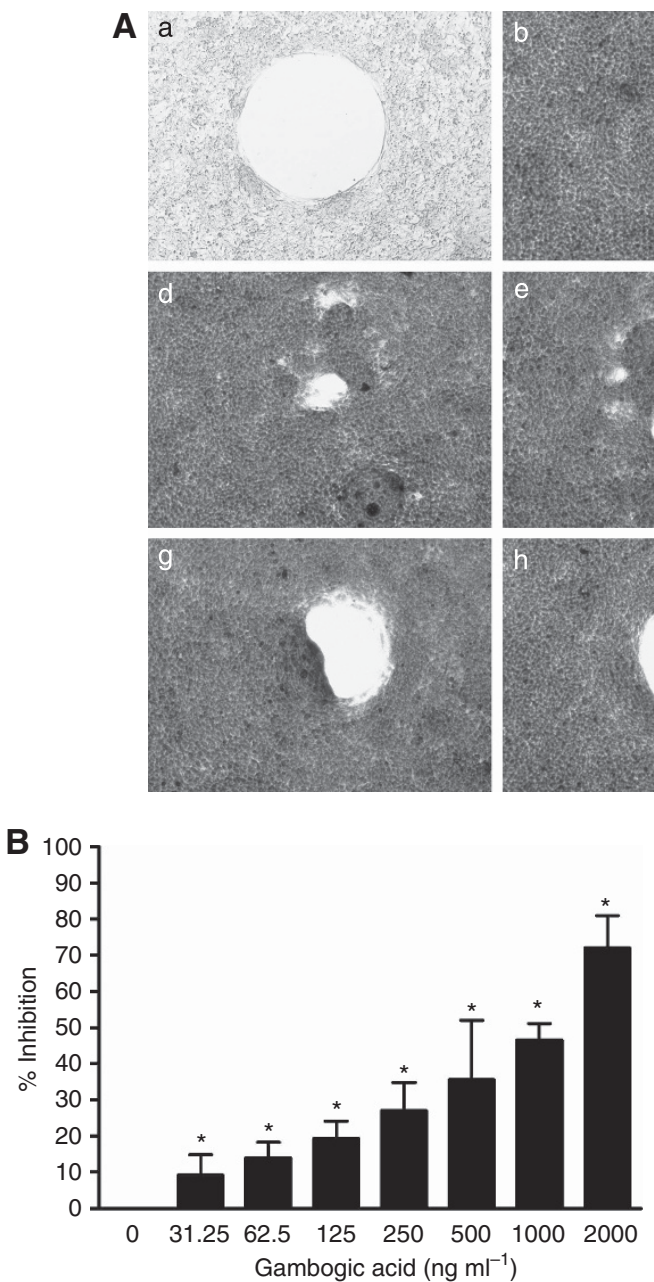
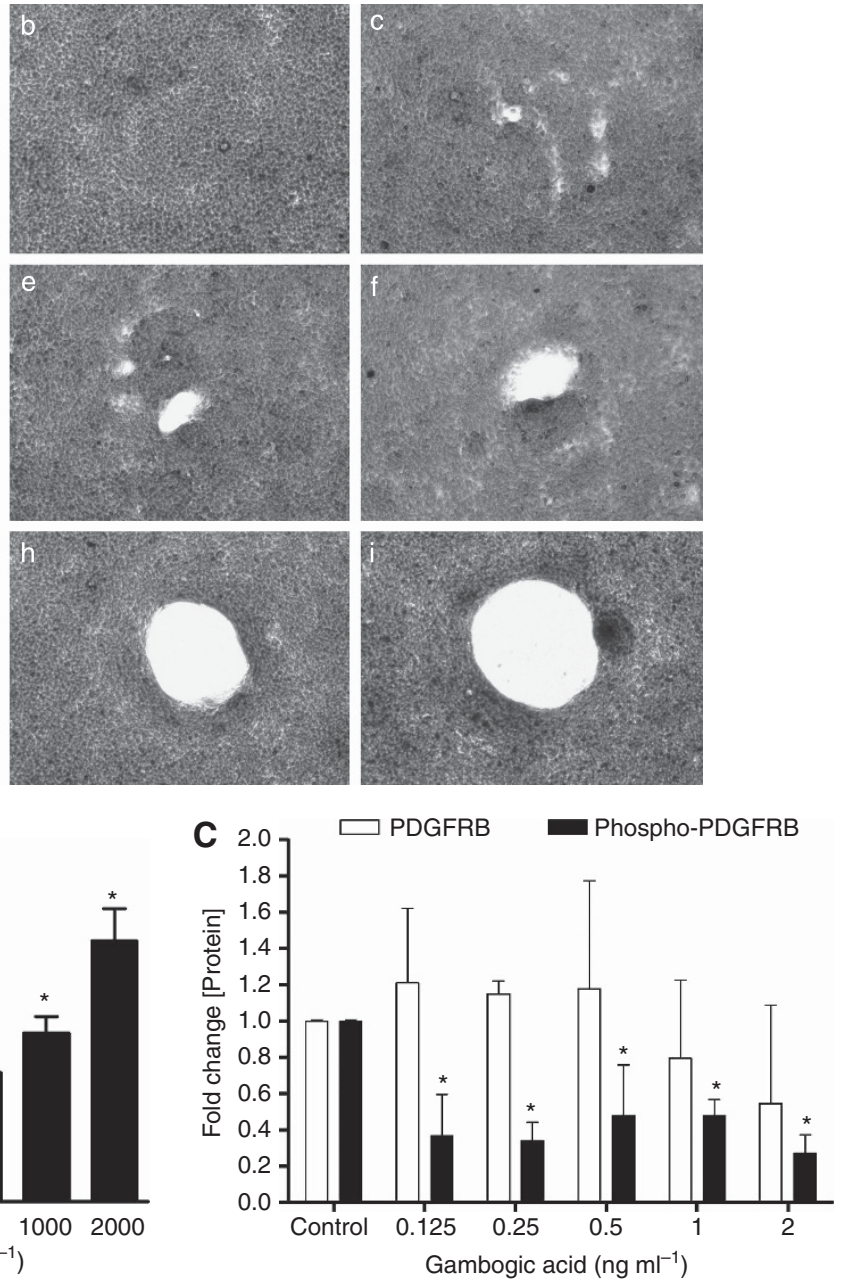

Figure 5 Gambogic acid inhibits the migration of meningioma cells in vitro. Eight different primary meningioma cells were plated in 24-well plates. The next day, the coating of the gap was removed followed by treatment for $24 \mathrm{~h}$ with either gambogic acid or vehicle (DMSO). Each gap was photographed after $24 \mathrm{~h}$, except for the first, which was photographed after $0 \mathrm{~h}$. (A) A representative experiment is shown. (a) The control group after 0 h. (b) The control group after $24 \mathrm{~h}$. (c) Treatment with $31.25 \mathrm{ng} \mathrm{ml}^{-1}$ gambogic acid. (d) Treatment with $62.5 \mathrm{ng} \mathrm{ml}^{-1}$ gambogic acid. (e) Treatment with I25 ng $\mathrm{ml}^{-1}$

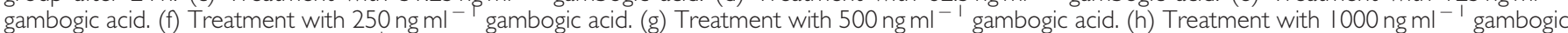
acid. (i) Treatment with $2000 \mathrm{ng} \mathrm{ml}^{-1}$ gambogic acid. (B) The concentration-dependent effect of gambogic acid on primary meningioma cells in a gap assay. The pictures were analysed using CellProfiler. The data are shown as the mean number of the inhibitory effect of gambogic acid compared with the uninhibited meningioma cells. (C) The primary meningioma cells were pre-treated with increasing concentrations of gambogic acid for I h. Then, the cells were stimulated with $100 \mathrm{ng} \mathrm{ml}^{-1}$ VEGFA for $10 \mathrm{~min}$ at $37^{\circ} \mathrm{C}$. The PDGFR $\beta$ expression and PDGFR $\beta$ phosphorylation were measured using a TaqMan Protein Assay. ( $\mathbf{B}$ and $\mathbf{C}$ ) $* P<0.05$, compared with the respective uninhibited cells. The bars represent the mean \pm s.d.

stimulation with VEGFA and PDGFB (data not shown) in a concentration-independent manner $(-67 \%$ on average compared with uninhibited cells, $P<0.05)$.

\section{DISCUSSION}

In this study, we demonstrated that VEGFA signals through PDGFR $\beta$ in meningioma cells in vitro. We measured the RNA and protein levels of angiogenesis-related genes with sensitive and novel techniques. The KDR was barely detectable in meningiomas with either qRT-PCR or the TaqMan Protein Assay. In contrast, $\operatorname{PDGFR} \beta$ was significantly upregulated in meningiomas compared with normal human brain samples. To provide evidence that VEGFA signalling through PDGFR $\beta$ has biological significance, we compared the effects of VEGFA and PDGFB on cell proliferation. Additionally, we demonstrated that stimulation with VEGFA induced $\operatorname{PDGFR} \beta$ tyrosine phosphorylation in meningiomas similar to PDGFB-stimulated PDGFR $\beta$. We also noted that the $\operatorname{PDGFR} \beta$ inhibitors sunitinib, tandutinib, and gambogic acid inhibit the migration of meningioma cells in vitro.

Meningiomas are highly vascularised tumours. Several studies have demonstrated the significance of VEGF in the proliferation and migration of meningiomas in which VEGF has been upregulated (Provias and Claffey, 1997; Christov et al, 1999; Lamszuz et al, 2000; Park et al, 2000; Yamasaki, 2000). Some groups have observed a correlation between the degree of VEGF expression and tumour vascularity or invasiveness (Samoto et al, 1995; Provias and Claffey, 1997). In contrast, Pietsch et al (1997) and Nishikawa et al (1998) could not find a relationship between VEGF expression and tumour vasculature (Pietsch et al, 1997; Nishikawa et al, 1998). Lamszuz et al (2000) noted a strong correlation between meningioma histological grade and VEGF expression, wherein increased VEGF expression was linked to higher WHO grades. However, Barresi and Tuccari (2010) showed the absence of correlation between VEGF expression and WHO 
grade (Barresi and Tuccari, 2010). Another study correlated VEGF expression and the recurrence of benign meningiomas (Yamasaki, 2000).

Uesaka et al (2007) quantified VEGFA expression in meningiomas compared with normal human brain samples using qRT-PCR and did not observe any changes in expression (Uesaka et al, 2007). In contrast, we observed that VEGFA RNA levels in vitro and in vivo were significantly increased in meningiomas compared with the brain but were downregulated compared with the arachnoidea and dura. The VEGFA expression in vitro and in vivo did not differ between WHO grades. Only the immunohistochemical staining of VEGFA showed increased levels in WHO ${ }^{\circ} \mathrm{III}$ meningiomas. This result was not confirmed by qRT-PCR or the Taqman protein assay results. Due to the low sample numbers of anaplastic meningiomas results can be biased especially when using only a single method. While VEGFA was upregulated on average, VEGFA expression in meningiomas displayed a broad distribution especially in vivo, which may explain opposing observations.

Several studies have examined KDR and FLT1 in meningiomas (Hatva et al, 1995; Otsuka et al, 2004; Huang et al, 2005; Preusser et al, 2012). Hatva et al (1995), Otsuka et al (2004), and Preusser et al (2012) determined KDR expression using either immunohistochemistry or in situ hybridisation. Hatva et al (1995) examined only three meningiomas, which cannot provide justifiable conclusions. The KDR protein expression was detected in $31.4 \%$ of specimens (Otsuka et al, 2004), and KDR mRNA was demonstrated in $44.4 \%$ of samples (Preusser et al, 2012). Those results show that KDR is not expressed in the majority of meningiomas. The data also provide no information about the expression level of KDR. Our finding that most examined meningiomas displayed no KDR protein expression does not contradict previous studies. In addition, the methods used may influence the results. Our immunohistochemical data for KDR expression show $87 \%$ positive specimens, but most meningiomas displayed low KDR levels.

Contradicting results were reported by Huang et al (2005), who measured KDR and FLT-1 expression in various brain tumours with qRT-PCR, using glyceraldehyde-3-phosphate dehydrogenase (GAPDH) to normalise and compare the results with those in HUVECs. Of the brain tumours that were examined, meningiomas had the highest KDR and FLT-1 levels. In contrast, we determined very low KDR RNA expression in most examined meningiomas.

Huang et al (2005) also observed higher VEGF receptor levels in meningiomas compared with the brain. Our data showed that KDR expression was significantly decreased in meningiomas compared with the brain. These RNA findings were verified by measuring KDR with a TaqMan Protein Assay. The reason for these contradictory results cannot be satisfactorily explained because the study does not state the number of examined samples. A few meningiomas show higher KDR expression compared with the brain. If a small specimen number was analysed, then that could account for the high KDR RNA levels.

Low or absent KDR expression suggests that mechanisms other than VEGFA signalling through KDR influence angiogenesis in meningiomas.

In addition to VEGF, PDGF signalling indirectly regulates angiogenesis. Yang (2001) showed that nearly all meningiomas express PDGFB and PDGFR $\beta$ in vitro, and both were increased in WHO ${ }^{\circ}$ II meningiomas. Several groups have proposed an autocrine mechanism in meningiomas, based on the co-expression of PDGFB and PDGFR $\beta$, which regulate growth (Wang et al, 1990; Figarella-Branger et al, 1994; Kuratsu et al, 1994; Mauro et al, 1995).

In contrast, we showed that PDGFB expression in vitro and in vivo was significantly decreased compared with the brain and dura. Further, PDGFR $\beta$ expression in vivo and in vitro rose in meningiomas compared with the brain. The significantly decreased in vitro $\mathrm{PDGFR} \beta$ RNA levels in WHO ${ }^{\circ} \mathrm{III}$ meningiomas were probably influenced by the small sample numbers $(n=5)$. The low number is due to their rarity among meningiomas. Moreover, surgically resected anaplastic meningiomas are almost always previously irradiated, which influences the cell quality.

High PDGFR $\beta$ expression combined with low KDR and PDGFB levels in meningiomas suggests that $\operatorname{PDGFR} \beta$ has a significant function in tumorigenesis in meningiomas.

We determined that the addition of exogenous VEGFA doubled cell proliferation in malignant IOMM-Lee and benign primary meningioma cells, comparable to exogenous PDGFB, suggesting that VEGFA signalling through PDGFR $\beta$ is biologically significant in meningiomas. To evaluate the functional effect of these findings, $\operatorname{PDGFR} \beta$ was inhibited with an anti-PDGFR $\beta$ neutralisation antibody or a PDGFR $\beta$ tyrosine kinase inhibitor before stimulation with VEGFA. The proliferative stimuli were abolished under these conditions. The control experiments with PDGFB stimulation showed that PDGFR $\beta$ inhibitors also neutralised PDGFB-induced proliferation. Why the presence of the PDGFR $\beta$ inhibitor did not significantly influence the PDGFB-induced proliferation rate in IOMM-Lee cells remains to be determined.

The cells were also inhibited with an anti-KDR neutralisation antibody or a KDR tyrosine kinase inhibitor before stimulation with VEGFA or PDGFB, respectively. As expected, the PDGFBinduced proliferation was not influenced by KDR inhibition. The VEGFA-induced proliferative stimuli were abolished after KDR inhibition in benign meningiomas but not in IOMM-Lee cells. There are two possible ways to interpret these results. First, the VEGFA-induced proliferative stimuli may be dependent on the binding of VEGFA to PDGFR $\beta$ as implied by the IOMM-Lee data. Second, the VEGFA-induced cell proliferation may rely on both KDR and PDGFR $\beta$ binding to VEGFA. Because some meningiomas express detectable KDR the second possibility is preferable to the first.

To further investigate the effect of VEGFA on PDGFR $\beta$ in meningiomas, we determined whether VEGFA caused the tyrosine phosphorylation of PDGFR $\beta$. The protein lysates from VEGFA-treated primary meningioma cells were analysed with a TaqMan Protein Assay, which allowed for the quantification of tyrosine phosphorylation in meningiomas. We demonstrated that VEGFA induces concentration-dependent PDGFR $\beta$ tyrosine phosphorylation in meningiomas after $10 \mathrm{~min}$. A comparison with PDGFB-induced meningioma cells showed a similar increase in the phosphorylation of PDGFR $\beta$. The effect of VEGFA on KDR was not investigated because KDR was not detectable in the meningiomas used. Thus, the data suggest that VEGFA mediates proliferation and migration through $\operatorname{PDGFR} \beta$, but not $\mathrm{KDR}$, in meningiomas.

To determine if selective PDGFR $\beta$ inhibitors, such as tandutinib, have a similar effect as sunitinib, which also inhibits KDR and several other receptor protein tyrosine kinases, we treated primary meningioma cells with these two tyrosine kinase inhibitors. Tandutinib suppressed cell migration in primary meningiomas as effectively as sunitinib, in spite of the fact that tandutinib only inhibits PDGFR $\beta$.

We also investigated the effect of gambogic acid on primary meningiomas. Recently Liu et al (2010) reported that gambogic acid inhibits cell migration by suppressing $\operatorname{PDGFR} \beta$ tyrosine phosphorylation. The treatment of meningiomas in vitro with gambogic acid significantly inhibited cell migration. Furthermore, gambogic acid inhibited the tyrosine phosphorylation of PDGFR $\beta$ after stimulation with VEGFA, independent of the gambogic acid concentration. These results support those of Liu et al (2010), showing that gambogic acid inhibits cell migration by suppressing PDGFR $\beta$ tyrosine phosphorylation.

The low expression or absence of $\mathrm{KDR}$ in meningiomas both in vitro and in vivo, combined with the elevated level of PDGFR $\beta$, suggests that VEGFA primarily regulates VEGF-mediated migration and proliferation through $\operatorname{PDGFR} \beta$, not $\mathrm{KDR}$, in 
meningiomas. This model is supported by our findings in which the stimulation of meningiomas in vitro with VEGFA upregulates cell proliferation and induces PDGFR $\beta$ tyrosine. Gambogic acid, tandutinib, and sunitinib were equally potent at inhibiting meningioma growth in vitro, suggesting that selective PDGFR $\beta$ inhibitors, such as gambogic acid and tandutinib, should be evaluated as potential therapies for recurrent and malignant meningiomas, possibly in combination with VEGF inhibitors.

\section{REFERENCES}

Barresi V, Tuccari G (2010) Increased ratio of vascular endothelial growth factor to semaphorin $3 \mathrm{~A}$ is a negative prognostic factor in human meningiomas. Neuropathology 30(5): 537-546

Carpenter AE, Jones TR, Lamprecht MR, Clarke C, Kang IH, Friman O, Guertin DA, Chang JH, Lindquist RA, Moffat J, Golland P, Sabatini DM (2006) CellProfiler: image analysis software for identifying and quantifying cell phenotypes. Genome Biol 7: R100

Cheng Y, Paz K (2008) Tandutinib, an oral, small-molecule inhibitor of FLT3 for the treatment of AML and other cancer indications. IDrugs 11(1): 46-56

Christov C, Lechapt-Zalcman E, Adle-Biassette H, Nachev S, Gherardi R (1999) Vascular permeability factor/vascular endothelial growth factor (VPF/VEGF) and its receptor flt-1 in microcystic meningiomas. Acta Neuropathol 98: 414-420

Cross M, Dixelius J, Matsumoto T, Claesson-Welsh L (2003) VEGF receptor signal transduction. Trends Biochem Sci 28: 488-494

Erickson HS, Albert PS, Gillespie JW, Wallis BS, Rodriguez-Canales J, Linehan WM, Gonzalez S, Velasco A, Chuaqui RF, Emmert-Buck MR (2007) Assessment of normalization strategies for quantitative RT-PCR using microdissected tissue samples. Lab Invest 87(9): 951-962

Ferrara N, Gerber HP, LeCouter J (2003) The biology of VEGF and its receptors. Nat Med 9(6): 669-676

Figarella-Branger D, Vagner-Capodano AM, Bouillot P, Graziani N, Gambarelli D, Devictor B, Zattara-Cannoni H, Bianco N, Grisoli F, Pellissier JF (1994) Platelet-derived growth factor (PDGF) and receptor (PDGFR) expression in human meningiomas: correlations with clinicopathological features and cytogenetic analysis. Neuropathol Appl Neurobiol 20(5): 439-447

Gu H, Wang X, Rao S, Wang J, Zhao J, Ren FL, Mu R, Yang Y, Qi Q, Liu W, Lu N, Ling H, You Q, Guo Q (2008) Gambogic acid mediates apoptosis as a p53 inducer through down-regulation of $\mathrm{mdm} 2$ in wild-type p53-expressing cancer cells. Mol Cancer Ther 7(10): 3298-3305

Hatva E, Kaipainen A, Mentula P, Jaaskelainen J, Paetau A, Haltia M, Alitalo K (1995) Expression of endothelial cell-specific receptor tyrosine kinases and growth factors in human brain tumors. Am J Pathol 146: 368-378

Holmes DI, Zachary I (2005) The vascular endothelial growth factor (VEGF) family: angiogenic factors in health and disease. Genome Biol 6 209-219

Huang H, Held-Feindt J, Buhl R, Mehdor nH, Mentlein R (2005) Expression of VEGF and its receptors in different brain tumors. Neurol Res 27: $371-377$

Jääskeläinen J (1986) Seemingly complete removal of histologically benign intracranial meningioma: Late recurrence rate and factors predicting recurrence in 657 patients. A multivariate analysis. Surg Neurol 26(5): 461-469

Kasibhatla S, Jessen KA, Maliartchouk S, Wang JY, English NM, Drewe J, Qiu L, Archer SP, Ponce AE, Sirisoma N, Jiang S, Zhang H-Z, Gehlsen KR, Cai SX, Green DR, Tseng B (2005) A role for transferrin receptor in triggering apoptosis when targeted with gambogic acid. Proc Natl Acad Sci USA 102(34): 12095-12100

Kelly LM, Yu J-C, Boulton CL, Apatira M, Li J, Sullivan CM, Williams I, Amaral SM, Curley DP, Duclos N, Neuberg D, Scarborough RM, Pandey A, Hollenbach S, Abe K, Lokker NA, Gilliland DG, Giese NA (2002) CT53518, a novel selective FLT3 antagonist for the treatment of acute myelogenous leukemia (AML). Cancer Cell 1(5): 421-432

Kuratsu JI, Seto H, Kochi M, Ushio Y (1994) Expression of PDGF, PDGFreceptor, EGF-receptor and sex hormone receptors on meningioma. Acta Neurochir (Wien) 131(3): 289-293

Lamszuz K, Lengler U, Schmidt NO, Stavrou D, Ergun S, Westphal M (2000) Vascular endothelial growth factor, hepatocyte growth factor/ scatter factor, basic fibroblast growth factor, and placenta growth factor

\section{ACKNOWLEDGEMENTS}

This study was supported by grants from the Else UebelmesserStiftung. We are grateful to Anita Lal (UCSF, USA) for kindly providing the IOMM-Lee cell line.

Supplementary Information accompanies the paper on British Journal of Cancer website (http://www.nature.com/bjc) in human meningiomas and their relation to angiogenesis and malignancy. Neurosurgery 46: 938-947

Liu Y, Li W, Ye C, Lin Y, Cheang T-Y, Wang M, Zhang H, Wang S, Zhang L, Wang S (2010) Gambogic acid induces G0/G1 cell cycle arrest and cell migration inhibition via suppressing $\mathrm{PDGF}$ receptor $\beta$ tyrosine phosphorylation and Racl activity in rat aortic smooth muscle cells. J Atheroscler Thromb 17(9): 901-913

Louis D, Ohgaki H, Wiestler O, Cavenee W, Burger P, Jouvet A, Scheithauer B, Kleihues P (2007) The 2007 WHO classification of tumours of the central nervous system. Acta Neuropathol 114(2): 97-109

Mahmood A, Caccamo DV, Tomecek FJ, Malik GM (1993) Atypical and malignant meningiomas: a clinicopathological review. Neurosurgery 33(6): 955-963

Mauro A, Di Sapio A, Mocellini C, Schiffer D (1995) Control of meningioma cell growth by platelet-derived growth factor (PDGF). J Neurol Sci 131(2): 135-143

McMullen KP, Stieber VW (2004) Meningioma: current treatment options and future directions. Curr Treat Options Oncol 5(6): 499-509

Mendel DB, Laird AD, Xin X, Louie SG, Christensen JG, Li G, Schreck RE, Abrams TJ, Ngai TJ, Lee LB, Murray LJ, Carver J, Chan E, Moss KG Haznedar JÖ, Sukbuntherng J, Blake RA, Sun L, Tang C, Miller T, Shirazian S, McMahon G, Cherrington JM (2003) In vivo antitumor activity of SU11248, a novel tyrosine kinase inhibitor targeting vascular endothelial growth factor and platelet-derived growth factor receptors. Clin Cancer Res 9(1): 327-337

Motzer RJ, Hoosen S, Bello CL, Christensen JG (2006) Sunitinib malate for the treatment of solid tumours: a review of current clinical data. Expert Opin Investig Drugs 15(5): 553-561

Nakasu S, Fukami T, Jito J, Nozaki K (2009) Recurrence and regrowth of benign meningiomas. Brain Tumor Pathol 26(2): 69-72

Nishikawa R, Cheng S, Nagashima R, Huang H, Cavenee W, Matsutani M (1998) Expression of vascular endothelial growth factor in human brain tumors. Acta Neuropathol 96: 453-462

Otsuka S, Tamiya T, Ono Y, Michiue H, Kurozumi K, Daido S, Kambara H, Date I, Ohmoto $\mathrm{T}$ (2004) The relationship between peritumoral brain edema and the expression of vascular endothelial growth factor and its receptors in intracranial meningiomas. J Neurooncol 70(3): 349-357

Park K, Kim JH, Nam DH, Lee JI, Kim JS, Hong SC, Shin HJ, Eoh W, Park K (2000) Vascular endothelial growth factor expression under ischemic stress in human meninigiomas. Neurosci Lett 283: 45-48

Pfister C, Tatagiba MS, Roser F (2011) Selection of suitable reference genes for quantitative real-time polymerase chain reaction in human meningiomas and arachnoidea. BMC Res Notes 4: 275

Pietsch T, Valter MM, Wolf HK, von Deimling A, Huang HJ, Cavenee WK, Wiestler OD (1997) Expression and distribution of vascular endothelial growth factor protein in human brain tumors. Acta Neuropathol 93: 109-117

Preusser M, Hassler M, Birner P, Rudas M, Acker T, Plate KH, Widhalm G, Knosp E, Breitschopf H, Berger J, Marosi C (2012) Microvascularization and expression of VEGF and its receptors in recurring meningiomas: pathobiological data in favor of anti-angiogenic therapy approaches. Clin Neuropathol 31: 352-360

Provias J, Claffey K, delAguila L, Lau N, Feldkamp M, Guha A (1997) Meningiomas: role of vascular endothelial growth factor/ vascular permeability factor in angiogenesis and peritumoral edema Neurosurgery 40: 1016-1026

Qiang L, Yang Y, You Q-D, Ma Y-J, Yang L, Nie F-F, Gu H-Y, Zhao L, Lu N, Qi Q, Liu W, Wang X-T, Guo Q-L (2008) Inhibition of glioblastoma growth and angiogenesis by gambogic acid: an in vitro and in vivo study. Biochem Pharmacol 75(5): 1083-1092 
Riemenschneider MJ, Perry A, Reifenberger G (2006) Histological classification and molecular genetics of meningiomas. Lancet Neurol 5(12): 1045-1054

Samoto K, Ikezaki K, Ono M, Shono T, Kohno K, Kuwano M, Fukui M (1995) Expression of vascular endothelial growth factor and its possible relation with neovascularization in human brain tumors. Cancer Res $\mathbf{5 5}$ 1189-1193

Schittenhelm J, Mittelbronn M, Roser F, Tatagiba M, Mawrin C, Bornemann A (2006) Patterns of SPARC expression and basement membrane intactness at the tumour-brain border of invasive meningiomas. Neuropathol Appl Neurobiol 32(5): 525-531

Uesaka T, Shono T, Suzuki SO, Nakamizo A, Niiro H, Mizoguchi M, Iwaki T, Sasaki T (2007) Expression of VEGF and its receptor genes in intracranial schwannomas. J Neurooncol 83: 259-266
Wang J, Nister M, Hermansson M, Westermark B, Ponten J (1990) Expression of PDGF beta-receptors in human meningioma cells. Int $\mathrm{J}$ Cancer 46: 772-778

Yamasaki F (2000) Recurrence of meningiomas. Cancer 89: 1102-1110

Yamazaki Y, Morita T (2006) Molecular and functional diversity of vascular endothelial growth factors. Mol Divers 10: 515-527

Yancopoulos GD, Davis S, Gale N, Rudge J, Wiegand S, Holash J (2000) Vascular specific growth factors and blood vessel formation. Nature 407: $242-248$

Yang S (2001) Expression of PDGF and its receptor as well as their relationship to proliferating activity and apoptosis of meningiomas in human meningiomas. J Clin Neurosci 8(4): 49-53

Yu J, Ustach C, Kim H (2003) Platelet-derived growth factor signaling and human cancer. J Biochem Mol Biol 36: 49-59

This work is published under the standard license to publish agreement. After 12 months the work will become freely available and the license terms will switch to a Creative Commons Attribution-NonCommercial-Share Alike 3.0 Unported License. 